\title{
Demotivation and Discipline in Nigerian Hospitals Case Study: Babcock University Teaching Hospital
}

\author{
Ikechi-Ekpendu, Chioma \\ Department of Political Science and Public Administration, Babcock University
}

\begin{abstract}
Employee Demotivation and Discipline in Babcock University Teaching Hospital carries a certain amount of responsibility for the motivation and welfare of its workforce. Organisations and institutions require full engagement and commitment of its workers to achieve optimum job performance. Where engagement, commitment and discipline could mean different things to different people, it is expedient to understand what drives an individual. The warning sign of demotivation which requires attention and addressed quickly can encourage employee contentment and professional retention. In an environment like Nigeria where demotivation is common in government owned institutions and hospitals most especially, it is worthy of research on why there seems to be demotivation in these hospitals and the reverse for institutions like Babcock University Teaching Hospital irrespective of numerous challenges hinging on it. Quantitative method of enquiry is used in this study to derive the solutions to the lurking challenges facing Medical institutions. This study discovers that certain motivational measures and discipline need to be applied to achieve excellent performance retainership and output of its staff.
\end{abstract}

Keywords: Commitment; Contentment; Development; Labour Law; Retainership; Training

\section{Introduction}

Motivation has been a common norm in organizations and also hospitals in Nigeria. Where the staff are motivated using various incentives to boost their work performance, especially where the services and skills of that individual or group of persons are required in the system, or where a factor or factors that cause or causes an employee to pursue work tasks or goals are put in place. Demotivation therefore rings an unusual bell in the ears of staff, who then brainstorm to know what actually demotivates them. BUTH as a case study has its peculiarities especially as it has to do with staff motivation and demotivation in relation to work performance. The level of work performance and output of staff in BUTH seems to attract the attention of other Consultants, Resident Doctors, Nurses, Lab Scientists, technologists and Therapist from various medical fields, Hospitals and institutions around it, irrespective of its turnover rate as observed in the country. 


\title{
International Conference on Research in HUMAN RESOURCE MANAGEMENT
}

\author{
March 7-9, 2019 , London- United Kingdom
}

Teaching Hospitals in Nigeria are perceived to have a lot of Beaurocracies and bottle necks that limit work productivity in various departments of the hospital and institution, according to Okotoni O, (2001) and Orhue, in Medical World Nigeria (2016) in an interview as Director of Human Reproductive and Research Center UBTH. And this has called for worry, when individuals and organizations are hesitant to take their loved ones to institutions like the teaching hospital. It has been observed that in BUTH, the case is not the same. Clearly reflecting is the fact that there seems to be motivating factors to the productivity level of BUTH staff as is being reflected in their work performance, and high limitation to bottle necks as seen in other hospitals.

Some scholars like Henry A. Lands Berger (1950) noticed a tendency for some people to work harder and perform better when they are being observed by researchers; and in agreement with Henry, Chip Conley posits that many managers struggle with the abstract concept of self-actualization and so focus on lower levels of pyramid instead. Chip further expanciated that in order to get most out of one's team, the institution or organization should make sure they get support for employees in other aspects of their lives outside work. Perhaps if employees are offered flexible working hours to give employees time to focus on their families and make sure they are paid fairly to assist them have a feeling of being financially stable; it could help in effective work productivity.

This further explains why Hawthorne effect studies shows why hospital workers will work harder if they know they are being observed, notwithstanding that Hawthorne does not believe in hovering over employees, institutions can provide regular feedback, letting your team know that you are aware of what they are capable of doing. When an employee knows that you care about them and their working condition, that can motivate them to work harder, especially when there is a feedback mechanism. It is very important for hospital managers or administrators to respond to their employee needs to avoid agitations as is seen in government hospitals in Nigeria; where they get to the extent of going on strikes, carry out demonstrations just to draw the attention of those in charge. (Akpunonu S, 2018). Challenges of such rear up at times when the Joint Health sector Union (JOHESU) and the federal government fail to reach a consensus especially when teaching hospitals across the country have lamented on the damage the action posed on the health sector for the adjustment of consolidated health salary structure (CONHESS) scale, specialist allowance, same scale promotion, employment of additional health professionals, implementation of court judgements, enhanced entry point, upward review of retirement age from 60 to 65years. Therefore, the early warning signs of demotivation should be looked out for and addressed immediately, as this would likely encourage employee contentment and talent retention (Page, 2019).

Employees pose some reasons for demotivation according to Michael Page (2019) being, Lack of Flexibility; short-term objectives or goals with no career vision where most people want to have a clear career objective in place to know that there is progression for them within the organization. 


\title{
International Conference on Research in HUMAN RESOURCE MANAGEMENT
}

\author{
March 7-9, 2019 , London- United Kingdom
}

Career visioning can be a useful process in setting clear, long-term goals for an employee so that they can proactively work towards projected outcomes. Another challenge is feeling undervalued, when an employee feels that efforts put in at work is not recognized or appreciated, soon the individual begins to lack energy and commitment in assigned role. Lack of development opportunities can also be a demotivating factor for employees. Regular training and development opportunities can boost employee motivation and engagement. Most employees will value ongoing learning potential and the sense that they're expanding and improving their skills and knowledge. If a workplace feels stagnant, non-progressive and uninspired employees' motivation levels will soon dwindle into demotivation. Poor leadership can be another demotivating factor to employees especially in hospitals. When strong leadership is absent or is negatively affecting the attitude of the team certain employees may start to feel discouraged. Leaders must have a flexible, all-encompassing approach to managing a team communicate clearly whilst instilling confidence and focus. If a particular team or individual is lacking motivation in the hospital or institution, it may be due to a lack of good leadership. Conflict at the workplace can pose a challenge and demotivational factor in the hospital. Healthy debate is often productive, but it's important to keep an eye out for any workplace intimidation or bullying. Some employees may feel worried to come forward about issues relating to a fellow colleague which is where an anonymous employee survey may help to reveal any problem areas, according to Page (2019). Some unrealistic workload can be a demotivating factor to employees, especially if the administration does not keep a watch on the expectations and demands or interests of the institution upon the employees; they might feel overburdened by a large, impossible workload. Disillusionment, stress and lose motivation can set in. Equally, if an employee has a workload that's too light or not varied enough, they might quickly lose interest.

The human resource is the most vital of all resources among other factors of production and the human capital is what distinguishes one organization from the other (Maimuna \& Rashad, 2013). Therefore, for organizations to survive and remain relevant and competitive, it is essential for them to be able to entice and maintain efficient and effective employees in a bid to enhance employee productivity and discipline (Sunia, 2014). Demotivation is the opposite of motivation. Hellriegel (1996) viewed motivation as any influence that portray, direct, or maintain people's goal directed behaviors. It refers to the driving force that makes an individual to act in a specific way. It is an inner drive that causes an individual to behave in a certain manner. The goal of most organizations is to improve productivity therefore factors of demotivation play significant roles in improving employee job satisfaction levels. This will in turn aid in improving an organization's productivity levels as disciplined employees increase an organizations output.

Employees make up the workforce of any organization as such they are an integral part of the organization. Aluko (2014) stated that an organization is only as good as the workforce that runs the 


\title{
International Conference on Research in HUMAN RESOURCE MANAGEMENT
}

\author{
March 7-9, 2019 , London- United Kingdom
}

organization. This is to say that when employees are motivated chances are that their morale would be high as such performance and productivity levels would increase thereby to a large extent boosting overall organizational performance level. In order to achieve high levels of productivity as such boost organizational performance or productivity, managers therefore need to continually seek ways of ensuring that their employees stay motivated. This is because a lack of employee motivation leads to reduced productivity which is harmful to organizational performance and continuous success.

Motivation is such a scheme which is applied to inspire, increase stamina and work ability by mentally conciliating the employees or workers to their work or job in a organization. In brief, Motivation is something which inspires one to work self-intentionally (Venkatesan, Varghese \& Ananthanarayanan, 2009). Discipline plays a major role in determining the future behaviors of employees, and it determines an organizations success. In order to be effective, discipline has to be applied fairly and consistently, with proper procedures and policies being utilized to ensure employees are of good discipline and conduct (Knight \& Ukpere, 2014). Demotivated employees may be a barrier to the purpose of an organization as their indiscipline will hinder organizational success.

\section{Statement of the problem}

Employees in organizations suffers from various factors which keeps them demotivated. These factors according to Halushchak and Halushchak (2016) include lack of a systematic approach to motivation of employees, motivation system is based only on financial incentives in the organizations; non-coordination of motivation system with the purpose of enterprise activity and needs of staff; inappropriate attention of leadership to the process of motivation; managers have the limited theoretical knowledge in personnel management; lack of experience and the inability of leaders to put into practice theoretical knowledge; ignoring the ideas of subordinates and incorrect assessment of the merits of subordinates and these does not keep the organizations employees disciplined.

James (2014) cited three warning signs of a demotivated workforce these include poor workplace atmosphere, slipping job standards and decreased productivity. He further stated that if any of these factors is observed to be trending downwards then there is a great chance that the organization is dealing with a demotivated workforce. Most businesses and organizations especially in the healthcare sector have failed to recognize the importance of motivation as a concept be it intrinsic or extrinsic in ensuring their employees discipline and this has led to their failure.

Burnout is a major challenge faced by employees in the healthcare sector such as BUTH. Burnout signifies feelings of physical and emotional exhaustion, alienation from others, and reduced personal accomplishment. In organizations that downsize through layoffs or hiring freezes, surviving employees have to work harder to cover the tasks of others. Fewer support staff or other resources are available to help get the job done. The new workplace offers scant advancement opportunities as management levels are eliminated and career paths are obscured thereby leading to demotivation by 


\title{
International Conference on Research in HUMAN RESOURCE MANAGEMENT
}

\author{
March 7-9, 2019 , London- United Kingdom
}

employees and reduction in employee discipline. The recession being experienced in Nigeria has limited pay increases and bonus pools, and this prompts people to ask what the payoff is for working so hard making them undisciplined and demotivated (Sahar, 2014).

\section{Objective of the study}

The general objective of this study is to evaluate the effect of demotivation and employee discipline in Nigerian hospitals using Babcock University Teaching Hospital as case study. Specific objectives are to:

1. Evaluate the effect of commitment on employee discipline at BUTH.

2. Determine the extent to which contentment affects employee discipline at BUTH.

3. Evaluate the effect the effect of career development on employee discipline at BUTH.

2. Determine the extent to which retainership affects employee discipline at BUTH.

\section{Research question}

This research was guided by the following research questions:

1. What is the effect of commitment on employee discipline at BUTH?

2. In what way does contentment affect employee discipline at BUTH?

3. How does career development affect employee discipline at BUTH?

4. Does retainership affect employee discipline at BUTH?

\section{Research Hypothesis}

$\mathbf{H}_{01}$ : there is no significant relationship between commitment and employee discipline at BUTH.

$\mathbf{H}_{02}$ : there is no significant relationship between contentment and employee discipline at BUTH.

$\mathbf{H}_{03}$ : there is no significant relationship between career development and employee discipline at BUTH.

$\mathbf{H}_{04}$ : there is no significant relationship between retainership and employee discipline at BUTH.

\section{Theoretical Review}

This study is based on the Maslow's and Herzberg's Theory as they seek to explain the effect of motivation on employee discipline.

\section{Maslow's Theory}

Maslow states that the human desire to satisfy one's needs acts as a motivator influencing their performance positively. He represents these needs as a hierarchy of five categories: physiological, safety, love / social, self esteem, and self-actualization. This theory focuses on the notion that individuals are driven by unfulfilled needs, and that the fulfillment of needs at the bottom end of the pyramid only leads to the pursuit for the fulfillment of those at the higher end (Maslow, 


\title{
International Conference on Research in HUMAN RESOURCE MANAGEMENT
}

\author{
March 7-9, 2019 , London- United Kingdom
}

1954). This theory suggested that for an individual to behave in an unselfish manner (disciplined), every need has to be fulfilled that is both deficiency and growth needs. Therefore, in as much as individuals are interested in satisfying their desires, they are advancing towards growth, which is selfactualization.

In the business setting, this implies that if workers were unable to satisfy their desires, there would be a loss of morale to work and perform excellently in the discharge of their jobs to the organization. Maslow believed that needs cannot be fully satisfied citing that needs that are more or less achieved stops to be a motivator. Therefore, organizations in a bid to improve employee discipline need to recognize the position of members of its workforce in relation to the hierarchy so as to be able to motivate them accordingly bearing in mind that motivational tools should be tailored to meeting their desires (Robbins, 2001).

\section{Herzberg's Theory}

Herzberg's two factors theory suggests that the absence of hygiene factors cause job dissatisfaction and the presence of demotivation factors result in employee indiscipline. Herzberg established that factors which appeared to ensure an employee's job satisfaction were connected to the job contents or the aspects of the job itself and he referred to them as motivators, meanwhile, factors which appeared to cause employees dissatisfaction were connected to the job context; and he referred to them as hygiene factors (Herzberg, 2000).

Hygiene factors are factors that will eliminate dissatisfaction when present; examples are company policy, basic needs, status, working environment, salary, supervision etc. while motivators are those factors that will result in demotivation and lack of interest in the job when not fulfilled and this could result in employees looking outside the organization for employment. Hygiene elements are described as upkeep elements considered important in evading dissatisfaction. On the other hand, these elements single-handedly do not ensure employee job fulfillment and high levels of motivation. These are factors not directly concerned with the job but concerned with the job context (Smerek \& Peterson, 2007). These factors are termed hygiene factors because their presence ensures a reasonable level of satisfaction and their absence can cause dissatisfaction.

Hence, it is imperative that organization make available hygiene elements in order to maximize employee discipline, however to it is much more important to ensure that motivators are present since these are the factors that motivate employees and eventually result in satisfaction. Motivators include job associated aspects including thought-provoking tasks, work achievements, acknowledgment and responsibility, chances for advancement and growth, recognition for achievement (Lumley, Coetzee Tladinyane \& Ferreira, 2011). Motivated and contented workers are better positioned to be more committed as such productive than those who are merely not dissatisfied. 


\section{International Conference on Research in HUMAN RESOURCE MANAGEMENT}

March 7-9, 2019 , London-United Kingdom

\section{Methodology}

The design adopted for this study is the quantitative research design using the descriptive survey design. This design was considered in order to investigate the relationships that exist among variables of the research. Data were collected through the primary source of data collection (Questionnaire). The research instrument was validated and reliability was carried out using the Cronbach alpha analysis. A total of two hundred employees of BUTH were surveyed using a structured questionnaire to elicit various information from the respondents. The conceptual model of the study is as shown in Figure 3.1. Data was analyzed by inferential statistics (regression analysis) using the statistical package for service solutions (SPSS).

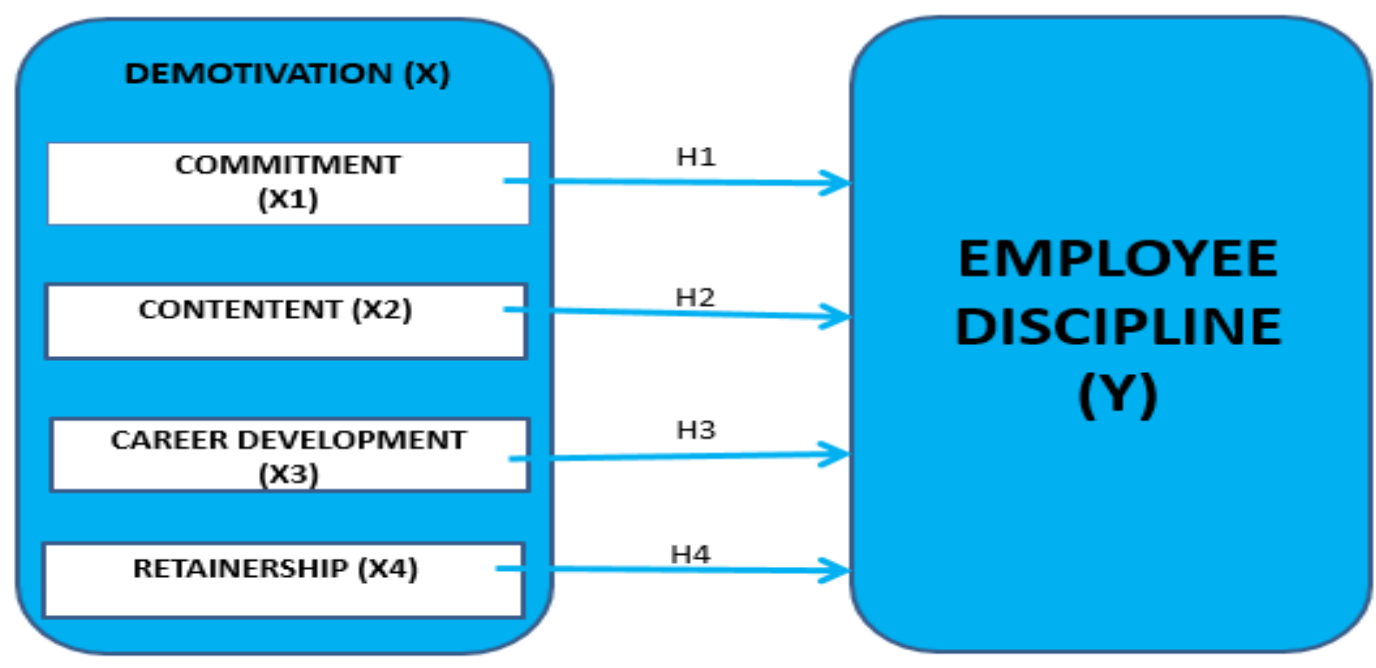

Source: Researcher's Conceptual Model (2019)

\section{Data Presentation, Analysis and Findings}

Two hundred questionnaires were distributed to employees. One hundred and seventy six questionnaires were retrieved indicating a eighty eight percent response rate. Table 1 shows the demographic and descriptive distribution of respondents.

Table 1: Demographic and Descriptive Distribution of Respondents

\begin{tabular}{|l|l|l|l|}
\hline Demographic and Personal Information & \multicolumn{2}{l|}{ Population of Respondents } \\
\hline Variable & Information & Frequency (N) & Percentage (\%) \\
\hline \multirow{3}{*}{ Gender } & Male & 74 & 58.0 \\
\cline { 2 - 4 } & Female & 102 & 42.0 \\
\hline \multirow{4}{*}{ Age } & $18-27$ & 42 & 23.9 \\
\cline { 2 - 4 } & $28-37$ & 62 & 35.2 \\
\cline { 2 - 4 } & $38-47$ & 46 & 26.1 \\
\hline
\end{tabular}




\section{International Conference on Research in HUMAN RESOURCE MANAGEMENT}

March 7 - 9, 2019 , London - United Kingdom

\begin{tabular}{|l|l|l|l|}
\hline \multirow{4}{*}{$\begin{array}{l}\text { Academic } \\
\text { Qualifications }\end{array}$} & $48-57$ & 21 & 11.9 \\
\cline { 2 - 4 } & 58 and Above & 5 & 2.8 \\
\cline { 2 - 4 } & Ph.D & 9 & 5.1 \\
\cline { 2 - 4 } & MBA/MSC & 40 & 22.7 \\
\cline { 2 - 4 } & BSC/HND/RM/RN & 53 & 30.1 \\
\cline { 2 - 4 } & OND/NCE & 35 & 19.9 \\
\cline { 2 - 4 } & Undergraduate & 14 & 8.0 \\
\cline { 2 - 4 } & SSCE & 25 & 14.2 \\
\hline Work Status & Non- Medical & 64 & 36.4 \\
\cline { 2 - 4 } & Medical & 112 & 63.6 \\
\hline
\end{tabular}

From Table 1, the study revealed that majority of the respondents are female (58.0\%), are between the ages of $28-37$ years (35.2\%), have BSc/HND/RM/RN qualifications (30.1\%) and are of the medical status work line (63.6\%).

\section{Restatement of Hypothesis 1:}

There is no significant relationship between commitment and employee discipline at BUTH.

Table 2.1 Model Summary

\begin{tabular}{|l|r|r|r|r|r|}
\hline $\begin{array}{l}\text { Mode } \\
\mathrm{I}\end{array}$ & \multicolumn{1}{|c|}{$\mathrm{R}$} & $\mathrm{R}$ Square & $\begin{array}{c}\text { Adjusted R } \\
\text { Square }\end{array}$ & $\begin{array}{c}\text { Std. Error of } \\
\text { the Estimate }\end{array}$ & $\mathrm{F}$ \\
\hline 1 & $.317^{\mathrm{a}}$ & .100 & .095 & 3.25883 & 19.390 \\
\hline
\end{tabular}

a. Predictors: (Constant), Commitment

Table 2.2 Coefficients $^{\mathrm{a}}$

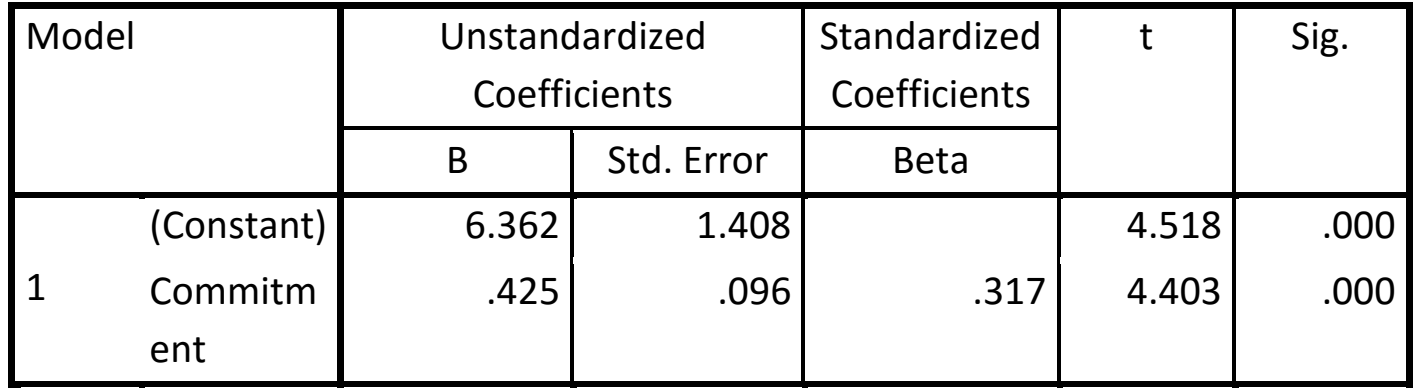

a. Dependent Variable: Employee Discipline

Model 1 for $\left(H_{01}\right)$ is stated as $y_{1}=f\left(x_{1}\right)$ and $y_{1}=\alpha_{0}+\beta_{1} x_{1}+\mu=6.362+0.425 x_{1}$ 


\section{International Conference on Research in HUMAN RESOURCE MANAGEMENT}

March 7 - 9, 2019 , London-United Kingdom

\section{Interpretation}

The results in table 2.1 and 2.2 shows that there is a statistically determinant relationship between commitment and employee discipline at BUTH. The null hypothesis that there is no significant relationship between commitment and employee discipline at BUTH is thereby rejected considering $\mathrm{P}<0.05$. The coefficient of determination $\left(R^{2}\right)$ indicates that commitment explains $(10.0 \%)$ in the differences of employee discipline at BUTH, while the increasing degree in commitment will increase employee discipline at BUTH by (0.317).

\section{Restatement of Hypothesis 2:}

There is no significant relationship between contentment and employee discipline at BUTH.

Table 3.1 Model Summary

\begin{tabular}{|l|r|r|r|r|l|}
\hline $\begin{array}{l}\text { Mode } \\
I\end{array}$ & R & R Square & $\begin{array}{c}\text { Adjusted R } \\
\text { Square }\end{array}$ & $\begin{array}{r}\text { Std. Error of } \\
\text { the Estimate }\end{array}$ & $\mathrm{F}$ \\
\hline 1 & $.383^{\mathrm{a}}$ & .146 & .142 & 3.17409 & 29.854 \\
\hline
\end{tabular}

a. Predictors: (Constant), Contentment

Table 3.2 Coefficients $^{\mathrm{a}}$

\begin{tabular}{|c|c|c|c|c|c|c|}
\hline \multirow{2}{*}{\multicolumn{2}{|c|}{ Model }} & \multicolumn{2}{|c|}{$\begin{array}{c}\text { Unstandardized } \\
\text { Coefficients }\end{array}$} & \multirow{2}{*}{$\begin{array}{l}\text { Standardized } \\
\text { Coefficients }\end{array}$} & \multirow[t]{2}{*}{$\mathrm{t}$} & \multirow[t]{2}{*}{ Sig. } \\
\hline & & $B$ & Std. Error & & & \\
\hline & (Constant) & 8.543 & .757 & & 11.287 & .000 \\
\hline 1 & $\begin{array}{l}\text { Contentme } \\
\text { nt }\end{array}$ & .342 & .063 & .383 & 5.464 & .000 \\
\hline
\end{tabular}

a. Dependent Variable: Employee Discipline

Model 2 for $\left(\mathrm{H}_{02}\right)$ is stated as $\mathrm{y}_{2}=f\left(\mathrm{x}_{2}\right)$ and $\mathrm{y}_{2}=\alpha_{0}+\beta_{2} \mathrm{x}_{2}+\mu=8.543+0.342 \mathrm{x}_{2}$

The results in table 3.1 and 3.2 shows that there is a statistically determinant relationship between contentment and employee discipline at BUTH. The null hypothesis that there is no significant relationship between contentment and employee discipline at BUTH is thereby rejected considering $P<0.05$. The coefficient of determination $\left(R^{2}\right)$ indicates that contentment explains $(14.6 \%)$ in the differences of employee discipline at BUTH, while the increasing degree in contentment will increase employee discipline at BUTH by (0.383). 


\section{International Conference on Research in HUMAN RESOURCE MANAGEMENT}

March 7 - 9, 2019 , London-United Kingdom

\section{Restatement of Hypothesis 3:}

There is no significant relationship between career development and employee discipline at BUTH.

Table 4.1 Model Summary

\begin{tabular}{|l|r|r|r|r|l|}
\hline $\begin{array}{l}\text { Mode } \\
\mathrm{I}\end{array}$ & $\mathrm{R}$ & $\mathrm{R}$ Square & $\begin{array}{c}\text { Adjusted R } \\
\text { Square }\end{array}$ & $\begin{array}{r}\text { Std. Error of } \\
\text { the Estimate }\end{array}$ & $\mathrm{F}$ \\
\hline 1 & $.461^{\mathrm{a}}$ & .213 & .208 & 3.04876 & 46.959 \\
\hline
\end{tabular}

a. Predictors: (Constant), Career Development

Table 4.2 Coefficients ${ }^{\mathrm{a}}$

\begin{tabular}{|c|c|c|c|c|c|}
\hline \multirow[t]{2}{*}{ Model } & \multicolumn{2}{|c|}{$\begin{array}{l}\text { Unstandardized } \\
\text { Coefficients }\end{array}$} & \multirow{2}{*}{$\begin{array}{c}\begin{array}{c}\text { Standardize } \\
\mathrm{d} \\
\text { Coefficients }\end{array} \\
\text { Beta }\end{array}$} & \multirow[t]{2}{*}{$\mathrm{t}$} & \multirow[t]{2}{*}{ Sig. } \\
\hline & B & $\begin{array}{l}\text { Std. } \\
\text { Error }\end{array}$ & & & \\
\hline (Constant) & 8.243 & .658 & & 12.535 & .000 \\
\hline Career Development & .370 & .054 & .461 & 6.853 & .000 \\
\hline
\end{tabular}

a. Dependent Variable: Employee Discipline

Model 3 for $\left(H_{03}\right)$ is stated as $y_{3}=f\left(x_{3}\right)$ and $y_{3}=\alpha_{0}+\beta_{3} x_{3}+\mu=8.243+0.370 x_{3}$

The results in table 4.1 and 4.2 shows that there is a statistically determinant relationship between career development and employee discipline at BUTH. The null hypothesis that there is no significant relationship between career development and employee discipline at BUTH is thereby rejected considering $\mathrm{P}<0.05$. The coefficient of determination $\left(R^{2}\right)$ indicates that career development explains (21.3\%) in the differences of employee discipline at BUTH, while the increasing degree in career development will increase employee discipline at BUTH by $(0.461)$.

\section{Restatement of Hypothesis 4:}

There is no significant relationship between retainership and employee discipline at BUTH.

Table 5.1 Model Summary

\begin{tabular}{|l|r|r|r|r|r|}
\hline $\begin{array}{l}\text { Mode } \\
\mathrm{I}\end{array}$ & $\mathrm{R}$ & $\mathrm{R}$ Square & $\begin{array}{c}\text { Adjusted R } \\
\text { Square }\end{array}$ & $\begin{array}{r}\text { Std. Error of } \\
\text { the Estimate }\end{array}$ & $\mathrm{F}$ \\
\hline 1 & $.503^{\mathrm{a}}$ & .253 & .249 & 2.96846 & 59.074 \\
\hline
\end{tabular}

a. Predictors: (Constant), Retainership 


\title{
International Conference on Research in HUMAN RESOURCE MANAGEMENT
}

\author{
March 7 - 9, 2019 , London- United Kingdom
}

Table 5.2 Coefficients $^{\mathrm{a}}$

\begin{tabular}{|c|c|c|c|c|c|c|}
\hline \multirow{2}{*}{\multicolumn{2}{|c|}{ Model }} & \multicolumn{2}{|c|}{$\begin{array}{l}\text { Unstandardized } \\
\text { Coefficients }\end{array}$} & \multirow{2}{*}{$\begin{array}{c}\text { Standardized } \\
\text { Coefficients } \\
\text { Beta }\end{array}$} & \multirow[t]{2}{*}{$t$} & \multirow[t]{2}{*}{ Sig. } \\
\hline & & B & Std. Error & & & \\
\hline & (Constant) & 5.810 & .894 & & 6.496 & .000 \\
\hline 1 & $\begin{array}{l}\text { Retainershi } \\
\mathrm{p}\end{array}$ & .500 & .065 & .503 & 7.686 & .000 \\
\hline
\end{tabular}

a. Dependent Variable: Employee Discipline

Model 4 for $\left(\mathrm{H}_{04}\right)$ is stated as $\mathrm{y}_{4}=\mathrm{f}\left(\mathrm{x}_{4}\right)$ and $\mathrm{y}_{4}=\alpha_{0}+\beta_{4} \mathrm{x}_{4}+\mu=5.810+0.500 \mathrm{x}_{4}$

The results in table 5.1 and 5.2 shows that there is a statistically determinant relationship between retainership and employee discipline at BUTH. The null hypothesis that there is no significant relationship between retainership and employee discipline at BUTH is thereby rejected considering $P<0.05$. The coefficient of determination $\left(R^{2}\right)$ indicates that retainership explains $(25.3 \%)$ in the differences of employee discipline at BUTH, while the increasing degree in retainership will increase employee discipline at BUTH by (0.503).

\section{Discussion}

Findings of this study has shown that demotivation is a strong predictor of employee discipline. This is in consonance with the of Hamre and Kaasboll (2008) that absence of both motivators and demotivators could simply leave workers with a neutral feeling about their job thereby influencing their discipline. These findings agree with Centers and Bugental (2007) in their study of the relationship between motivational factors and worker's performance using the two factor theory where effectiveness and efficiency were used as measures of performance. It was discovered that there was a significant relationship between both motivation factors and worker efficiency and discipline levels. Taylor and Vest (1992) further supported in his statement that extrinsic motivation factors tend to be rated more highly than intrinsic motivation factors especially for those at lower levels of the organization. He further stated that employees who enjoy friendly relationships with their co-workers both within and outside the workplace tend to be very efficient and discipline at their jobs than those who don't.

These findings corroborate the findings of Lin (2013) in the research titled assessment of intrinsic and extrinsic motivation on employee productivity. Findings from the study revealed that intrinsic factors like employee well-being and organizational policy have a significant effect on workers effectiveness which is also a measure of productivity. This was further validated by Jibowo (2007) establishing that intrinsic motivation is a significant predictor of employee effectiveness and plays a major role in improving worker performance and productivity levels in an organization. He 


\title{
International Conference on Research in HUMAN RESOURCE MANAGEMENT
}

\author{
March 7-9, 2019 , London- United Kingdom
}

further stated that managers should ensure that employee's well-being is taken seriously and that workers are extrinsically well rewarded to remain intrinsically disciplined in their jobs.

\section{Conclusion and recommendations}

The study concluded that demotivation signicantly affects employee discipline thereby organizations should ensure that their employees stay motivated at all times so as to help the organization achieve its aims and objectives. A demotivated employee will not give his/her best on the job. Demotivation in this study was measured using employee commitment, contentment, career development and retainership and these were seen to affect employee discipline at various degrees. The study provides the following recommendations to organizations so as to keep their employees motivated and not demotivated while also ensuring their discipline and success on the job. The management of organizations should create a supportive, pleasant full working environment internally, in order to keep their employees motivated and disciplined. Employees should be trained according to the present content of the environment. Organizations can spur motivation and discipline among their employees by rewards thereby achieving both individual and organizational objectives. Finally, the study recommends that the facilities provided to the employees should be standard and aid their execution of tasks assigned to them with a well-designed system for complaints and challenges by the employees as these will not make them demotivated and will promote discipline among the employees. For further studies on comparative analysis might be required. 


\title{
International Conference on Research in HUMAN RESOURCE MANAGEMENT
}

\author{
March 7 - 9, 2019 , London- United Kingdom
}

\section{References}

Adekunle A. (2018) Health workers strike cripples activities in Hospitals nationwide. http://www.Vanguardngr.com. Retrieved February 24, 2019

Akpunonu S. (2018) Hospitals Count loses as Health workers strike persist. The Guradian newspaper. http://www.guardian.ng Retrieved February 24, 2019

Centers, R. \& Bugental D. E. (2007), Intrinsic and extrinsic motivations among different aspects of the working population. Journal of Applied Psychology, 15(1), 7-20.

Ghana. Kpakpakpa.com. Retrieved 13th January, 2017 from http://kpakpakpa.com/spotlight/challenges-facing-manufacturing-in-nigeria-ghana/

Halushchak, O. \& Halushchak, M. (2016). The causes of appearance and ways of staff's demotivation solving in organizations. Socio-Economic Problems and the State. 14 (1), 138-144.

Hamre, G. A. \& Kaasboll, J. (2008). Motivation and Demotivation: A Case Study of the Malawian Health Management Information System. Electronic Journal of Health Informatics, 3(2), 1-11

Hellriegel, D. S. (1996). Management 7th ed. Cincinnati Ohio: South Western college publishing.

Herzberg, F. (2000). The motivation to work, New York: Willy and Son Publishers.

James, C. (2014). The warning signs of a demotivated workforce. LinkedIn, retrieved on January 6, 2019 from https://www.youtube.com/watch?v=ZIVT 9LUJMc

Jibowo, A. A. (2007). - Effect of motivators and hygiene factors on job performance among extension workers in the former Western State of Nigeriall. The Quarterly Journal of Administration, 12(1), 45-54.

Knight, X. \& Ukpere, W. I. (2014). The Effectiveness and Consistency of Disciplinary Actions and Procedures within a South African Organisation. Mediterranean Journal of Social Sciences, 5(4), 589-596

Lin, H. F. (2007). Effects of extrinsic and intrinsic motivation on employee knowledge sharing intentions. Journal of Information Science, 33(2), 135-149.

Lumley, E. J., Coetzee, M., Tladinyane, R., \& Ferreira, N. (2011). Exploring the job Satisfaction and organizational commitment of employees in the information technology Environment. Southern African Business Review, 15(1), 100-118. 


\section{International Conference on Research in HUMAN RESOURCE MANAGEMENT}

March 7 - 9, 2019 , London-United Kingdom

Maimuna, M. N., \& Rashad, Y. F. (2013). The impact of employee training and development on employee productivity. Global Journal of Commerce and Management Perspective, 2(6), 91-93

Maslow, A. (1954). Motivation and Personality. New York: New York Harper\& Row.

Okotoni O. (2001) Problems and Prospects of Nigerian Beaurocracy-Semantic Scholar. http://www.problems\&prospects.com. Retrieved February 24, 2019.

Orhue E. (2016) How University of Ilorin Teaching Hospital recorded IVF Feat. http://www.medicalworldnigeria.com. Retrieved February 24, 2019.

Robbins, S. P., \& Coulter, M. (2009). Management. New Jersey: Prentice Hall.

Sahar, F.A. (2014). Person Demotivation in Organizational Life. International Journal of Business and Social Science, 5(1), 215-219.

Smerek, R. \& Peterson, M. (2007). Examining Herzberg's theory: Improving job satisfaction among non-academic employees at a university. Research in Higher Education, 48(2), 229-250.

Sunia, F. (2014). Factors that predict employee retention in profit and not-for-profit Organizations. Global Journal of Human Resource Management 2(4), 1-8.

Taylor, G. S., \& Vest, M. J. (1992). Pay comparison and pay satisfaction among public sector employees. Public Personnel Management, 21(4), 445 - 454.

Venkatesan, R., Varghese, K. \& Ananthanarayanan, R. (2009) Motivation and demotivation 'causefactors' for engineers in construction organisations. In: Dainty, A.R.J. (Ed) Procs 25th Annual ARCOMConference, 7-9 September 2009, Nottingham, UK, Association of Researchers in Construction Management, 145-53. 